IRA-International Journal of Management \& Social Sciences

ISSN 2455-2267; Vol.07, Issue 02 (2017)

Pg. no. 294-301

Institute of Research Advances

http://research-advances.org/index.php/RAJMSS

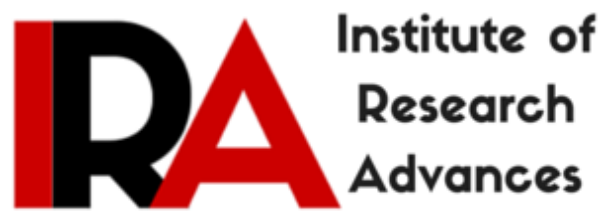

\title{
Marketing Channels, Marketing Margins, Costs and Price Spreads: A Case Study of Bathinda District of Punjab
}

Parveen Rani

Assistant Professor, Economics

Christ University, Bengaluru, India.

Dr. Shakuntla Gupta

Professor, Economics

Punjabi University, Patiala, India.

Type of Review: Peer Reviewed.

DOI: http://dx.doi.org/10.21013/jmss.v7.n2.p20

\section{How to cite this paper:}

Rani, P., \& Gupta, S. (2017). Marketing Channels, Marketing Margins, Costs and Price Spreads: A Case Study of Bathinda District of Punjab. IRA-International Journal of Management \& Social Sciences (ISSN 2455-2267), 7(2), 294-301. doi:http://dx.doi.org/10.21013/jmss.v7.n2.p20

(C) Institute of Research Advances

\section{(cc) EY-NC}

This work is licensed under a Creative Commons Attribution-Non Commercial 4.0 International License subject to proper citation to the publication source of the work.

Disclaimer: The scholarly papers as reviewed and published by the Institute of Research Advances (IRA) are the views and opinions of their respective authors and are not the views or opinions of the IRA. The IRA disclaims of any harm or loss caused due to the published content to any party. 


\section{ABSTRACT}

The present study is carried out with the objective of studying the marketing channels because farmers producing agricultural produce are scattered in remote villages while consumers are in semiurban and urban areas. This produce has to reach consumers for its final use and consumption. There are different agencies and functionaries through which produce passes and reach the consumer. Therefore, it is important to study the various functionaries involved in the marketing of cotton crop. Besides, it is important to analyze the costs associated with the services rendered by the market functionaries, marketing margins and price spreads in the marketing of cotton. Such studies are useful for both the producers/sellers and the buyers/consumers because the former are interested in getting the highest price for their produce while the latter are interested in paying as low a price as possible. The present research paper provides some guidelines to the policy makers about the need of efficient marketing system.

Keywords: Consumers, Marketing channels, Producers

\section{Introduction}

Cotton often referred as "White Gold" has been in cultivation in India for more than five thousand years. India occupies the $2^{\text {nd }}$ place among the cotton growing countries of the world. The increased industrialization and urbanization in India is bringing about shifts in cotton consumption pattern. This in turn, has resulted in increased demand for cotton. The improvements in the production scenario as well as demand are determined by the improvements in the marketing system. The adage that marketing starts even before the production conveys the significance of the role of marketing in the development of agriculture. The development of an efficient marketing system is one of the major factors contributing to a quantum jump in agricultural production. The study of the marketing channels, marketing margins and costs assume special significance in agriculture state like Punjab where the programmes of marketing improvement have been launched.

\section{Objectives of the study}

The present study attempts to focus on the following objectives:

$>$ To find out the alternative channels in the marketing of cotton.

$>$ To assess the marketing costs, margins and price spread in the marketing of cotton.

$>$ To examine the producer's share in consumer's rupee.

$>$ To identify the constraints faced by the cotton growers in the marketing of cotton.

A number of studies in the past examined the marketing costs, margins and price spreads at regional and national levels. For instance, studies by Pavaskar, M.G. and et al. (1970), Rai, K.N. (1980), Bhupal, D.S. (1995), Krishnaiah, J. (1998), Ramamoorthy, K. and et al. (1999), Kulkarni, N.S. (1999), Kumar, N.R. and et al. (1999), Bhurao, J.S. (2012) examined the marketing channels, marketing costs and price spreads in the marketing of cotton. The present study examined the price spreads, marketing costs and margins among alternative marketing channels in case of cotton crop in Bathinda district of Punjab for the year 2013-2014 in which there is hardly any research regarding cotton. Further, these studies differ not only in respect of working out the price spreads in different marketing channels but also in respect of different methods used for computing price spreads. In the present study, price spreads are computed at a point of time by using mode method.

\section{Research Methodology}

To achieve the objectives of the study, primary data has been used, which were collected from producers, sellers, commission agents, and traders. Survey method has been used to collect the relevant 
data. A well prepared questionnaire has been used to collect primary data. The primary data is related to the year 2013-14.

For the collection of primary data, a three-stage stratification scheme has been adopted. At the first stage, the selection of Bathinda District is made as Bathinda is the largest producer of cotton in the Punjab state.

At the second stage, ten villages are sampled from the list of villages growing cotton having maximum area under the crop. The sampled villages are Phus Mandi, Jodhpur Romana, Mehta, Naruana,JassiPauwali, Deon, Ablu, MehmaSarja, Jandan Wala and Jeeda. From the selected villages, a sample of 200 farmers growing cotton crop has been taken. All efforts have been made to collect a sample of the population engaged in the production of the cotton. At the third stage, from each of two markets, a sample of 25 commission agents/traders has been randomly drawn from the list obtained from the Office of Market Committees and from other informed resources.

\section{Results and Discussion}

There exist four important marketing channels for cotton in Bathinda district of Punjab.

Channel-I: Producer-Miller-Consumer

Channel-II: Producer-Trader/Commission Agent-Miller-Consumer

Channel-III: Producer-Village Trader-Miller-Consumer

\section{Channel-IV: Producer-CCI}

The details of costs, margins and price spread in the marketing of cotton through all the channels, i.e., channel-I, channel-II, channel-III and channel-IV have been represented in the Tables 1.1, 1.2, 1.3 and 1.4. The table 1.1 shows that the consumer paid Rs. 5653.00 to purchase $64 \mathrm{~kg}$ of cotton seed during 201314. Transportation cost, plucking, loading and unloading were the main components of marketing costs at the producer's level. The producer paid Rs.500 per quintal on plucking, Rs.30 per quintal on transportation and Rs. 16.5 per quintal on loading and unloading. In channel-I, the producer incurred a cost equivalent to 9.7 per cent of the same. The producer sold the produce to millers. The millers paid market fee and rural development fund (RDF) each at a rate of 1 per cent and commission at a rate of 2.5 per cent in the market. Among the other components of costs at miller's level, the miller spent Rs.12.85 per quintal on weighing, Rs.25 per quintal on transportation, loading and unloading, Rs.30 per quintal on interest and insurance and Rs. 130 per quintal on ginning and processing. The millers incurred a cost of 7.7 per cent and earned 0.3 per cent of the consumer's rupee. Producer's share in consumer's rupee was found to be 82.3 per cent in channel-I.

Table 1.1

Price Spread of Cotton in Bathinda District Markets through Channel-I

\begin{tabular}{|l|l|l|l|}
\hline $\begin{array}{l}\text { Sr. } \\
\text { No. }\end{array}$ & \multicolumn{1}{|c|}{ Name of functionary } & \multicolumn{1}{|c|}{$\begin{array}{c}\text { Rs. Per } \\
\text { quintal }\end{array}$} & $\begin{array}{c}\text { \% of Consumer's } \\
\text { price }\end{array}$ \\
\hline 1 & Net share/price of producer & 4654 & 82.3 \\
\hline 2 & Costs incurred by producer & & \\
& I. Plucking cost & 500 & \\
& II. Transportation cost $\quad$ Loading \& Unloading & 30 & \\
& III. & 546.5 & 9.7 \\
\hline & Total cost & \\
\hline
\end{tabular}




\begin{tabular}{|c|c|c|c|}
\hline 3 & Producer's sale price/ Miller's purchase price & 5200.5 & \\
\hline 4 & \begin{tabular}{cl}
\multicolumn{2}{l}{ Costs incurred by miller } \\
I. & Commission @ 2.5 percent \\
II. & RDF @ 1 per cent \\
III. & Market fee @ 1 per cent \\
IV. & Weighing charges \\
V. & Transportation cost, Loading \& unloading \\
VI. & Interest and Insurance \\
VII. & Other cost \\
VIII. & Ginning and Processing costs \\
Total cost &
\end{tabular} & $\begin{array}{l}130 \\
52 \\
52 \\
12.85 \\
25 \\
30 \\
1.55 \\
130 \\
433.4\end{array}$ & 7.7 \\
\hline 5 & Actual cost borne by the miller & 5633.9 & \\
\hline 6 & $\begin{array}{l}\text { Sale proceeds recovered by Miller } \\
\text { I. } \quad \text { Value of cotton lint } \\
\text { II. } \quad \text { Value of cotton seed }\end{array}$ & $\begin{array}{l}1376 \\
4277\end{array}$ & \\
\hline 7 & Net Margin of Miller & 19.1 & 0.3 \\
\hline 8 & Miller's Sale Price / Consumer's Purchase Price & 5653 & 100 \\
\hline
\end{tabular}

Source: Field Survey, 2013-14

Channel: Producer-Miller-Consumer

The Table 1.2 shows that in channel-II, where commission agents or traders are involved, the producer received a net price of Rs.4604.00 per quintal which is equivalent to 81.4 per cent of the consumer's rupee after incurring a cost of 9.7 per cent of the same (Rs.546.5 per quintal). The producer paid Rs.500 per quintal on plucking and Rs.30 per quintal on transportation. The loading and unloading charges were found to be Rs.16.5 per quintal. The next intermediary, i.e., commission agent secured a net margin and incurred a cost of Rs.41.2 per quintal and Rs.281.2 per quintal respectively, which were equivalent to 0.7 per cent and 5.0 per cent of the consumer's rupee respectively. The commission agent/ trader expenses included commission @ 2.5 per cent, RDF @ 1 per cent, market fee @ 1 per cent, weighing charges, transportation, loading and unloading. Further, the commission agent/trader sold the produce to miller. The costs incurred by miller includes interest and insurance and ginning and processing cost. The net share of miller in the consumer's rupee was observed to be 0.4 per cent (Rs.20.1 per quintal). So, finally the consumer's purchase price of cotton lint and cotton seed was Rs.5653 per quintal.

Table 1.2

Price Spread of Cotton in Bathinda District Markets through Channel-II

\begin{tabular}{|c|c|c|c|}
\hline $\begin{array}{l}\text { Sr. } \\
\text { No. }\end{array}$ & Name of functionary & $\begin{array}{l}\text { Rs. Per } \\
\text { quintal }\end{array}$ & $\begin{array}{c}\% \text { of Consumer's } \\
\text { price }\end{array}$ \\
\hline 1 & Net share/price of producer & 4604 & 81.4 \\
\hline 2 & \begin{tabular}{cl}
\multicolumn{2}{l}{ Costs incurred by producer } \\
I. & Plucking cost \\
II. & Transportation cost \\
III. & Loading \& Unloading \\
Total cost &
\end{tabular} & $\begin{array}{l}500 \\
30 \\
16.5 \\
546.5 \\
\end{array}$ & 9.7 \\
\hline
\end{tabular}




\begin{tabular}{|c|c|c|c|}
\hline 3 & $\begin{array}{l}\text { Producer's sale price/ Commission Agent/ Trader's } \\
\text { purchase price }\end{array}$ & 5150.5 & \\
\hline 4 & $\begin{array}{cl}\text { Costs incurred by Commission Agent/ Trader } \\
\text { I. } & \text { Commission @ } 2.5 \text { percent } \\
\text { II. } & \text { RDF @ 1 per cent } \\
\text { III. } & \text { Market fee @ 1 per cent } \\
\text { IV. } & \text { Weighing charges } \\
\text { V. } & \text { Transportation cost, Loading \& Unloading } \\
\text { VI. } & \text { Other costs } \\
\text { Total cost } & \end{array}$ & $\begin{array}{l}128.8 \\
51.5 \\
51.5 \\
12.85 \\
35 \\
1.55 \\
281.2\end{array}$ & 5.0 \\
\hline 5 & Commission Agent/ Trader's margin/share & 41.2 & 0.7 \\
\hline 6 & $\begin{array}{l}\text { Commission Agent/ Trader's sale price/ Miller's purchase } \\
\text { price }\end{array}$ & 5472.9 & \\
\hline 7 & \begin{tabular}{ll}
\multicolumn{2}{l}{ Costs incurred by Miller } \\
I. $\quad$ Ginning and Processing cost \\
II. & Interest and Insurance \\
Total cost &
\end{tabular} & $\begin{array}{l}130 \\
30 \\
160\end{array}$ & 2.8 \\
\hline 8 & Actual Price borne by Miller & 5632.9 & \\
\hline 9 & $\begin{array}{c}\text { Sale proceeds recovered by Miller } \\
\text { III. } \quad \text { Value of cotton lint } \\
\text { IV. } \quad \text { Value of cotton seed }\end{array}$ & $\begin{array}{l}1376 \\
4277\end{array}$ & \\
\hline 10 & Net Margin of Miller & 20.1 & 0.4 \\
\hline 11 & Miller's Sale Price / Consumer's Purchase Price & 5653 & 100 \\
\hline
\end{tabular}

Source: Field Survey, 2013-14

\section{Channel: Producer-Trader/Commission Agent-Miller-Consumer}

In channel-III, the producer sold the produce to village trader. The producer paid Rs.500 per quintal on plucking. The transportation, loading, unloading and weighing charges were to be paid by village trader. The village trader received a net margin equivalent to 1.5 per cent of consumer's rupee (Rs.85.5 per quintal) after incurring a cost of 1.1 per cent of the same (Rs.61 per quintal). In other words, the village trader sold the produce to miller at Rs.5200.5 per quintal. The miller received a net margin and incurred a cost equivalent to Rs.19.1 per quintal and 433.4 per quintal, i.e., 0.3 per cent and 7.7 per cent of the consumer's rupee respectively. The components of marketing costs at the miller's level were commission (Rs.130 per quintal), RDF (Rs.52 per quintal), market fee (Rs.52 per quintal), weighing charges (Rs.12.85 per quintal), transportation, loading and unloading (Rs.25 per quintal), interest and insurance (Rs.30 per quintal), ginning and processing (Rs.130 per quintal). Finally the miller's sale price or consumer's purchase price was Rs.5653 per quintal and the producer's share in consumer's rupee in this channel was found to be 81.4 per cent. 
Table 1.3

Price Spread of Cotton in Bathinda District Markets through Channel-III

\begin{tabular}{|c|c|c|c|}
\hline $\begin{array}{l}\text { Sr. } \\
\text { No. }\end{array}$ & Name of functionary & $\begin{array}{l}\text { Rs. Per } \\
\text { quintal }\end{array}$ & $\begin{array}{c}\% \text { of Consumer's } \\
\text { price }\end{array}$ \\
\hline 1 & Net share/price of producer & 4554 & 80.6 \\
\hline 2 & $\begin{array}{c}\text { Costs incurred by producer } \\
\text { I. } \quad \text { Plucking cost }\end{array}$ & 500 & 8.8 \\
\hline 3 & Producer's sale price/ Village trader's purchase price & 5054 & \\
\hline 4 & \begin{tabular}{cl}
\multicolumn{2}{l}{ Costs incurred by Village trader } \\
I. & Transportation cost \\
II. & Loading \& Unloading \\
III. & Weighing cost \\
Total cost &
\end{tabular} & $\begin{array}{l}30 \\
20 \\
11 \\
61\end{array}$ & 1.1 \\
\hline 5 & Village trader's margin/share & 85.5 & 1.5 \\
\hline 6 & Village trader's sale price/ Miller's purchase price & 5200.5 & \\
\hline 7 & \begin{tabular}{cl}
\multicolumn{2}{l}{ Costs incurred by miller } \\
I. & Commission @ 2.5 percent \\
II. & RDF @ 1 per cent \\
III. & Market fee @ 1 per cent \\
IV. & Weighing charges \\
V. & Transportation cost, Loading \& unloading \\
VI. & Interest and Insurance \\
VII. & Other cost \\
VIII. & Ginning and Processing costs \\
Total cost &
\end{tabular} & $\begin{array}{l}130 \\
52 \\
52 \\
12.85 \\
25 \\
30 \\
1.55 \\
130 \\
433.4\end{array}$ & 7.7 \\
\hline 8 & Actual cost borne by the miller & 5633.9 & \\
\hline 9 & $\begin{array}{l}\text { Sale proceeds recovered by Miller } \\
\text { I. } \quad \text { Value of cotton lint } \\
\text { II. } \quad \text { Value of cotton seed }\end{array}$ & $\begin{array}{l}1376 \\
4277\end{array}$ & \\
\hline 10 & Net Margin of Miller & 19.1 & 0.3 \\
\hline 11 & Miller's Sale Price / Consumer's Purchase Price & 5653 & 100 \\
\hline
\end{tabular}

Source: Field Survey, 2013-14

Channel: Producer-Village Trader-Miller-Consumer

The details of costs, margins and price spread in the marketing through channel-IV (Producer$\mathrm{CCI}$ ) have been shown in Table 1.4. The table shows that after purchasing the cotton from farmer, CCI 
gave it to miller for processing. The costs incurred by the producer were Rs.546.5 per quintal that is equivalent to 9.7 per cent of the consumer's rupee and received a net price of Rs.4654 per quintal, which is 82.3 per cent of the consumer's rupee. In this channel, all the components of marketing costs are incurred by the CCI and among the components, the maximum share was noticed for milling, i.e., Rs. 180 per quintal. The other components includes Rs.130 per quintal as commission, Rs.52 per quintal as rural development fund, Rs.52 per quintal as market fee, Rs.12.85 per quintal on weighing, Rs.25 per quintal on transportation, loading and unloading. Finally, the actual cost borne by the CCI was Rs.5653.9. But during the period 2013-14, this channel was not much prevalent because of higher price of cotton.

Table 1.4

Price Spread of Cotton in Bathinda District Markets through Channel-IV

\begin{tabular}{|c|c|c|c|}
\hline $\begin{array}{l}\text { Sr. } \\
\text { No. }\end{array}$ & Name of functionary & $\begin{array}{l}\text { Rs. Per } \\
\text { quintal }\end{array}$ & $\begin{array}{c}\% \text { of Consumer's } \\
\text { price }\end{array}$ \\
\hline 1 & Net share/price of producer & 4654 & 82.3 \\
\hline 2 & \begin{tabular}{cl}
\multicolumn{2}{l}{ Costs incurred by producer } \\
I. & Plucking cost \\
II. & Transportation cost \\
III. & Loading \& Unloading \\
Total cost &
\end{tabular} & $\begin{array}{l}500 \\
30 \\
16.5 \\
546.5\end{array}$ & 9.7 \\
\hline 3 & Producer's sale price/ CCI's purchase price & 5200.5 & \\
\hline 4 & $\begin{array}{cl}\text { Costs incurred by CCI } \\
\text { I. } & \text { Commission @ } 2.5 \text { percent } \\
\text { II. } & \text { RDF @ } 1 \text { per cent } \\
\text { III. } & \text { Market fee @ } 1 \text { per cent } \\
\text { IV. } & \text { Weighing charges } \\
\text { V. } & \text { Transportation cost, Loading \& unloading } \\
\text { VI. } & \text { Other costs } \\
\text { VII. } & \text { Milling charges } \\
\text { Total cost } & \end{array}$ & $\begin{array}{l}130 \\
52 \\
52 \\
12.85 \\
25 \\
1.55 \\
180 \\
453.4\end{array}$ & 8.0 \\
\hline 5 & Actual cost borne by CCI & 5653.9 & 100 \\
\hline
\end{tabular}

Source: Field Survey, 2013-14

Channel: Producer-CCI

\section{Conclusions}

It has been found that there exist four important marketing channels for cotton in Bathinda District of Punjab. Among them, the most predominant marketing channel observed is ProducerCommission Agent-Miller-Consumer. Findings related to marketing costs, margins and price spread reveal that producer gets 80 to 82 per cent of the consumer's rupee among alternative marketing channels of cotton crop. The share of the marketing costs is observed to be about 9 to 10 per cent of the consumer's 
rupee which is very high and needs to be reduced. Similarly, marketing margins also need to be minimized.

From the study, it has been found that farmers of Bathinda district are rational farmers. They are influenced by the market prices. The majority of them prefer to sell their produce in the proper market and not in village. This is amply brought by the study result that about 70 to 80 per cent of the produce is sold in the market and not in the village, the market price being higher than the village price. Thus, they harvest the part of the marketing gains as well. They tend to make the maximum use of the market information, which becomes available to them.

The important problems observed in the marketing of cotton are the deferred payments and predominance of prior price agreements with the purchasers. The study results highlighted that some marginal farmers sell their produce in village itself due to lack of transportation facilities, debt obligation and limited quantity of the produce which lead to the distress sales.

\section{Suggestions}

In order to reduce the marketing costs and to increase the producer's share in consumer's rupee, it is recommended that mandis should be equipped with modern marketing infrastructure like terminal market so that farmers may not face the problem of transportation, deferred payments, prior price agreement and low price of their produce etc. Government should also protect the farmers through guaranteed minimum support price and procurement price.

To overcome the practice of deferred payment, the banks should come forward to provide loans as well as for payment against their produce. The farmers should form their own marketing organizations, i.e., cooperatives and should pass the intermediaries in the marketing of the produce.

\section{References}

1. Bhupal, D.S., 1995. Behaviour of Costs and Margins in the Marketing of Cotton over time in Haryana. Indian Journal of Agricultural Marketing, 9 (12: 64-65)

2. Bhurao, J.S., 2012. Cotton Marketing and Production in India - A Study. Golden Research Thoughts, 2 (2)

3. Krishnaiah, J., 1998. An Empirical Analysis of Cotton Marketing in Warangal District of Andhra Pradesh. Indian Journal of Agricultural Marketing, 12 (1-2: 6-15)

4. Kumar, N.R. and et al., 1999. Performance of Market Intermediaries in Adoni Regulated Market of Kurnool District (AP). Agricultural Marketing, 42 (36-41)

5. Kulkarni, N.S., 1999. Marketing of Cotton in India. Cotton Marketing, Handbook of cotton in India, Indian Society for Cotton Improvement (ISCI), Mumbai

6. Pavaskar, M.G. and et al., 1970. Marketing Margins in Cotton. Economic and Political Weekly, 5 (13: 41-47)

7. Rai, K.N., 1980. Economic Aspects of Cotton Marketing in Haryana. Agricultural Marketing, 23 (19-25)

8. Ramamoorthy, K. and et al., 1999. Credit and Marketing Linkages among the Cotton Farmers of Warangal. Indian Journal of Agricultural Marketing, 13 (2: 85-91) 